\title{
¿Son idóneos para el oficio eclesiástico los divorciados que contraen nuevo matrimonio civil?
}

\section{May Divorced People Who Have Remarried Civilly Marriages Serve in Ecclesiastical Offices?}

\begin{abstract}
Antonio VIANA
Profesor Ordinario de Organización Eclesiástica Facultad de Derecho Canónico. Universidad de Navarra aviana@unav.es
\end{abstract}

Resumen: La exhortación apostólica Amoris laetitia y los Sínodos de 2014 y 2015 han tratado de la situación de los católicos que después de un divorcio contraen un matrimonio reconocido por las leyes civiles. Allí se ha propuesto una mayor participación de esos fieles en la vida de la Iglesia, de modo que se plantea el problema de si pueden recibir cargos públicos y ministerios eclesiales, como pueden ser la participación en Consejos pastorales, la enseñanza de la religión en escuelas católicas o la catequesis en las parroquias. En este estudio se analiza el concepto de la idoneidad canónica a la luz de las enseñanzas del Magisterio de la I glesia y las disposiciones generales. En la segunda parte del trabajo se sugieren distintos criterios sobre supuestos claros y otros de carácter dudoso.

Palabras clave: Amoris laetitia, Divorciados vueltos a casar, Idoneidad canónica, Oficio eclesiástico, Ministerios laicales.
Abstract: The apostolic exhortation Amoris laetitia and the 2014 and 2015 Synods have addressed the situation of Catholics who enter into a civil marriage following divorce. Greater involvement of such faithful in the life of the Church has been proposed, which raises the issue of whether they may serve in church offices and ministries, such as participation in pastoral councils, teaching religion in Catholic schools or leading catechesis in parishes. The concept of canonical suitability is analyzed in light of the teachings of the Magisterium of the Church and other general provisions; the second part of the paper suggests different criteria in relation to clear positions and other, less clear-cut situations.

Keywords: Amoris laetitia, Divorced and Remarried Persons, Canonical Suitability, Ecclesiastical Office, Lay Ministries. 


\section{LA IDONEIDAD PARA EL OFICIO Y LAS SITUACIONES MATRIMONIALES IRREGULARES}

7 res son las expresiones principales incluidas en el título de este trabajo: idoneidad, oficio, católicos divorciados que se han vuelto a casar. La noción de idoneidad debe distinguirse de la habilidad o capacidad general de los fieles para el oficio eclesiástico, capacidad que en el sistema normativo actual es reconocida a todos los fieles que cumplan las debidas condiciones y no sólo a los clérigos ${ }^{1}$. En efecto, la distinción se emplea en el derecho administrativo canónico y viene expresada, por ejemplo, en el c. $228 \$ 1$ del CIC, donde se distingue entre la habilidad de los laicos para desempeñar oficios eclesiásticos (babiles sunt) y la idoneidad para hacerlo concretamente ${ }^{2}$. Mientras que la habilidad es la aptitud general para ser titulares de los oficios que no estén reservados a los clérigos, la idoneidad exige poseer las condiciones requeridas por el derecho universal y particular para los distintos oficios, condiciones que son valoradas por la autoridad eclesiástica competente.

Los cánones generales sobre el oficio eclesiástico regulan los procedimientos jurídicos para que un fiel pueda ser designado titular de un cargo público en la Iglesia, así como las formas canónicas de cesación ${ }^{3}$. En esa normativa se establece que hay dos requisitos necesarios para poder ser promovido a un oficio: en primer lugar, estar en comunión con la Iglesia; en segundo lugar, ser idóneo, es decir, poseer las cualidades que el derecho exija. La carencia de las cualidades exigidas hace inválida la provisión cuando aquéllas son exigidas expresamente ad validitatem; de lo contrario resultaría válida, aunque podría rescindirse por la autoridad administrativa ${ }^{4}$.

La segunda palabra clave incluida en el título del presente estudio es of $i$ cio eclesiástico. La terminología de la organización eclesiástica distingue entre oficios, encargos, funciones o ministerios, términos que no siempre son usados en sentido unívoco ${ }^{5}$. En efecto, hay munera que no llegan a ser propia-

${ }^{1}$ Para una introducción general al instituto de la idoneidad, cfr. B. EJEH, The principle of suitability in the provision of ecclesiastical offices in the 1983 Code of Canon Law, Ius Ecclesiae 20 (2008) 569-592.

2 El c. $228 \$ 1$ dispone: «Los laicos que sean considerados idóneos tienen capacidad de ser llamados por los sagrados pastores para aquellos oficios eclesiásticos y encargos que pueden cumplir según las prescripciones del derecho».

${ }^{3}$ Cfr. cc. 146-183 (provisión) y 184-196 (pérdida de un oficio eclesiástico) del CIC.

${ }^{4}$ Cfr. c. 149 del CIC.

${ }^{5}$ Cfr. P. ERDö, Elementos de un sistema de las funciones públicas en la Iglesia según el Código de Derecho Canónico, Ius Canonicum 33 (1993) 541-552; y A. MonTAN, Ministeria, munera, officia. I laici tito- 
mente oficios, por tratarse de nombramientos que no implican la provisión de un cargo público establemente constituido: así, por lo que se refiere a la participación, incluso estable, en funciones litúrgicas o en tareas de catequesis. A los efectos de esta investigación, el oficio es entendido como una función o grupo de funciones establemente constituidas en la organización eclesiástica que son desempeñadas por uno o varios titulares; o bien, por decirlo sencillamente con palabras del CIC, una función establemente constituida que es ejercida para un fin espiritual (c. $145 \$ 1$ ). Es claro que el oficio cumple una misión de primer orden en el derecho canónico, porque es la institución que permite el desarrollo continuado de tareas eclesiásticas que precisan una atención estable y permanente ${ }^{6}$.

La Iglesia aplica un conjunto de criterios, asentados históricamente hasta configurar un cierto sistema, para comprobar la idoneidad de los titulares de oficios eclesiásticos, como pueden ser: la exigencia de documentos y declaraciones firmadas; los exámenes que pueden realizarse para comprobar la idoneidad; las entrevistas personales de la autoridad con los candidatos al oficio; las consultas individuales y colegiales que tengan lugar con anterioridad al nombramiento; los informes personales que pueda necesitar la autoridad ${ }^{7}$.

Por fin, la tercera expresión incluida en el título de este trabajo. Hay muchos supuestos concretos que pueden estudiarse sobre el alcance canónico de la idoneidad. Algunos revisten una especial importancia pastoral. Así, la exhortación apostólica de Juan Pablo II Familiaris consortio, de 22-XI-1981, trataba de las situaciones irregulares en relación con el matrimonio: matrimonios a prueba, uniones de hecho, católicos unidos solamente con matrimonio civil, separados y divorciados no casados de nuevo, divorciados casados de nuevo ${ }^{8}$. Entre esas situaciones irregulares podemos destacar por su difusión las de aquellos fieles casados canónicamente que, después de haber obtenido el divorcio según las leyes del Estado, contraen un nuevo matrimonio civil.

lari di uffici e di ministeri (cann. 228, 230, 274): precisazioni terminologiche, en GRUPPO ITALIANO DOCENTI DI DIRITTO CANONICO (a cura di), I laici nella ministerialità della Chiesa: XXVI Incontro di Studio, Milano 2000, 99-134.

${ }^{6}$ Sobre la naturaleza y finalidad del oficio eclesiástico, remito a mi libro Organización del gobierno en la Iglesia, Eunsa, Pamplona ${ }^{32010,75-82 . ~}$

7 Cfr. A. Viana, La comprobación de la idoneidad para el oficio eclesiástico y el orden sagrado, Ius Ecclesiae 28 (2016) 345-366.

8 Cfr. Juan Pablo II, exh. ap. Familiaris consortio, 22-XI-1981, AAS 74 (1982) 81-191, nn. 79-84. 
La situación de estos fieles plantea diversas cuestiones. Problemas difíciles, en los que están implicados diversos bienes que deben defenderse: la indisolubilidad del vínculo conyugal por derecho divino, la condición moral de los cónyuges y su situación en la Iglesia y ante los demás fieles, el bien de los hijos fruto de estas uniones.

Con ocasión de haberse celebrado los sínodos sobre la familia, convocados por el papa Francisco en los años 2014 y 2015, los medios de comunicación han tratado ampliamente de la situación en la Iglesia de los divorciados vueltos a casar, y especialmente de las condiciones de acceso a los sacramentos de la eucaristía y de la penitencia, cuestión que aquí no será estudiada directamente. $\mathrm{Al}$ mismo tiempo, las asambleas sinodales y el papa Francisco han propuesto una mayor participación de esos fieles en la vida de la Iglesia, y de este modo se ha planteado la cuestión de si pueden recibir encargos eclesiales y con qué alcance.

La pregunta podría ser formulada así: ¿son idóneos para el oficio eclesiástico aquellos fieles que se han divorciado y se han vuelto a casar civilmente? ¿Impide su situación en la Iglesia, o al menos desaconseja, la titularidad de oficios y también de otras funciones públicas, como pueden ser la participación en consejos pastorales diocesanos o parroquiales, la enseñanza de la religión en colegios católicos o en centros públicos, la catequesis en la parroquia?

Mi estudio intenta responder a estas preguntas y se divide en dos partes: la primera resume las principales enseñanzas del magisterio de la Iglesia sobre esta materia y expone también el contenido de algunas normas canónicas generales. En la segunda parte propongo una reflexión personal sobre la pregunta que da título a este trabajo.

El presupuesto metodológico de conocer el magisterio y las normas eclesiales sobre la materia parece necesario aquí, sobre todo a causa de los aspectos morales implicados y la variedad de voces e interpretaciones sobre la situación de los divorciados unidos en matrimonio civil. Esa diversidad interpretativa es más acusada en ambientes secularizados de países de antigua tradición cristiana y tiene también sus reflejos entre los fieles. Por tales motivos, excusando el esquematismo que esto puede suponer, me parece oportuno ante todo recordar el contenido de los principales documentos de la Iglesia universal por orden cronológico. Hay que tener en cuenta que la documentación que será resumida a continuación es variada, puesto que se incluirán documentos magisteriales pontificios, enseñanzas del catecismo universal y de las congregaciones romanas, normas canónicas generales, conclusiones de algunos síno- 
dos, declaraciones interpretativas. Esto comporta que el contenido dogmático, jurídico y moral de esta documentación tenga distinto alcance. En particular, habrán de valorarse especialmente los documentos del magisterio ordinario pontificio?.

\section{ENSEÑANZAS DEL MAGISTERIO DE LA IGLESIA Y DISPOSICIONES GENERALES}

2.1. Exh. ap. «Familiaris consortio» (1981): acogida a los divorciados casados de nuevo, condiciones de acceso a la eucaristía y la penitencia, valoración de las diversas situaciones

La exhortación apostólica Familiaris consortio, de 22-XI-1981, fue publicada después de la celebración en 1980 de un sínodo de obispos sobre la familia. En el n. 84 de aquel documento, Juan Pablo II se refería a la «plaga», que ya entonces asolaba los ambientes católicos, de los que recurren al divorcio para pasar a una nueva unión. El santo Pontífice señalaba ante todo un claro principio: «La Iglesia, instituida para conducir a la salvación a todos los hombres, sobre todo a los bautizados, no puede abandonar a sí mismos a quienes -unidos ya con el vínculo matrimonial sacramental- han intentado pasar a nuevas nupcias. Por lo tanto procurará infatigablemente poner a su disposición los medios de salvación».

En efecto, estos fieles son miembros de la Iglesia, de modo que no deben sentirse ajenos a ella ni excluidos de su vida y misión, sino llamados a participar en su vida. Cuando el documento de Juan Pablo II explica qué significa esto concretamente se refiere al aprovechamiento de los medios de santificación, las obras de caridad y justicia, la educación en la fe, las obras de penitencia ${ }^{10}$.

\footnotetext{
${ }^{9}$ Me limito, por tanto, al examen de documentos de diversa índole de la Iglesia universal y, más concretamente, de la Iglesia latina. Los documentos episcopales regionales o nacionales no son estudiados aquí directamente, salvo en algún caso. Algunas referencias a documentos regionales sobre los divorciados que contraen nuevo matrimonio civil pueden verse en F. R. AZNAR GIL J. R. FlECHA ANDRÉS, Admisión a la comunión eucarística de los divorciados y casados civilmente de nuevo, Salmanticensis 42 (1995) 240-245, especialmente.

${ }^{10}$ «En unión con el Sínodo exhorto vivamente a los pastores y a toda la comunidad de los fieles para que ayuden a los divorciados, procurando con solícita caridad que no se consideren separados de la Iglesia, pudiendo y aún debiendo, en cuanto bautizados, participar en su vida. Se les exhorte a escuchar la Palabra de Dios, a frecuentar el sacrificio de la misa, a perseverar en la oración, a incrementar las obras de caridad y las iniciativas de la comunidad en favor de la justicia, a educar a los hijos en la fe cristiana, a cultivar el espíritu y las obras de penitencia para implorar de este modo, día a día, la gracia de Dios»: Familiaris consortio, n. 84.
} 
De manera más concreta, Juan Pablo II recuerda y reafirma el criterio moral tradicional respecto a la participación de esos fieles en la comunión eucarística y en el sacramento de la penitencia; esa participación sacramental sólo es posible si se cumplen estrictas condiciones. Al precisar esta doctrina, el Pontífice enseña que la situación de esas personas contradice objetivamente lo que la eucaristía significa y actualiza, además del peligro de escándalo que se daría si esos fieles no se abstuvieran de aquella participación sacramental ${ }^{11}$.

Otro importante criterio de Familiaris consortio, que se repetirá en posteriores documentos de la Iglesia, es la necesidad de valorar bien las diversas situaciones, que no son iguales desde el punto de vista moral y pastoral: «En efecto, hay diferencia entre los que sinceramente se han esforzado por salvar el primer matrimonio y han sido abandonados del todo injustamente, y los que por culpa grave han destruido un matrimonio canónicamente válido. Finalmente están los que han contraído una segunda unión en vista a la educación de los hijos, y a veces están subjetivamente seguros en conciencia de que el precedente matrimonio, irreparablemente destruido, no había sido nunca válido» (n. 84).

En conclusión, los principios de Familiaris consortio son claramente contrarios a la posibilidad de la participación de los divorciados y vueltos a casar en oficios y funciones públicas eclesiásticas en el ámbito de los munera regendi, docendi y sanctificandi; es decir, de la liturgia, la enseñanza y las tareas de gobierno o auxiliares, ya que incluyen firmes enseñanzas sobre el peligro de escándalo y la irregularidad objetiva de la situación en la que se encuentran esos fieles. Así se entiende que Familiaris consortio, n. 84 prohíba bajo ningún pre-

11 «La Iglesia, no obstante, fundándose en la Sagrada Escritura reafirma su praxis de no admitir a la comunión eucarística a los divorciados que se casan otra vez. Son ellos los que no pueden ser admitidos, dado que su estado y situación de vida contradicen objetivamente la unión de amor entre Cristo y la Iglesia, significada y actualizada en la eucaristía. Hay además otro motivo pastoral: si se admitieran estas personas a la eucaristía, los fieles serían inducidos a error y confusión acerca de la doctrina de la Iglesia sobre la indisolubilidad del matrimonio. La reconciliación en el sacramento de la penitencia -que les abriría el camino al sacramento eucarístico- puede darse únicamente a los que, arrepentidos de haber violado el signo de la alianza y de la fidelidad a Cristo, están sinceramente dispuestos a una forma de vida que no contradiga la indisolubilidad del matrimonio. Esto lleva consigo concretamente que cuando el hombre y la mujer, por motivos serios -como, por ejemplo, la educación de los hijos-, no pueden cumplir la obligación de la separación, "asumen el compromiso de vivir en plena continencia, o sea de abstenerse de los actos propios de los esposos"»: Familiaris consortio, n. 84. La última cita, dentro del n. 84, corresponde a la homilía de Juan Pablo II, de 25-X-1980, en la clausura del sínodo de 1980 sobre la familia. 
texto pastoral realizar ceremonias para reconocer o bendecir la unión de los divorciados vueltos a casar ${ }^{12}$.

\section{2. $\mathrm{El} \mathrm{CIC} \mathrm{de} 1983$}

El CIC no contiene disposición específica sobre los fieles divorciados que se hayan vuelto a unir en matrimonio civil. Sin embargo, hay algunos cánones que indirectamente, al menos, pueden ayudar a precisar si esos fieles son idóneos para recibir oficios eclesiásticos o tareas que tengan una significación y alcance públicos en la sociedad eclesial. Pueden citarse, entre otros, los cc. 512 (composición del Consejo pastoral), 804 (selección de profesores de religión católica), $874 \$ 1.3^{\circ}$ y $893 \$ 1$ (requisitos de los padrinos de bautismo y confirmación), 915 (admisión a la sagrada comunión), etc. En la segunda parte del estudio comentaré con más detalle algunas de estas normas.

\subsection{Catecismo de la Iglesia católica (1992): imposibilidad de ejercer «ciertas responsabilidades eclesiales»}

El Catecismo subraya la indisolubilidad del vínculo matrimonial, especialmente en los números dedicados al sacramento del matrimonio y la peculiaridad de la nueva ley de Cristo, pero también en otros lugares del texto ${ }^{13}$. Es importante tener en cuenta la enseñanza de este texto doctrinal cuando recuerda en el n. 1615 que esta propiedad del matrimonio es, en realidad, un don de Dios, puesto que «Jesús no impuso a los esposos una carga imposible de llevar y demasiado pesada (cfr. Mt 11,29-30), más pesada que la Ley de Moisés. Viniendo para restablecer el orden inicial de la creación perturbado por el pecado, da la fuerza y la gracia para vivir el matrimonio en la dimensión nueva del Reino de Dios. Siguiendo a Cristo, renunciando a sí mismos, tomando sobre sí sus cruces (cfr. Mt 8,34), los esposos podrán "comprender" (cfr. Mt 19,11) el sentido original del matrimonio y vivirlo con la ayuda de Cristo. Esta gracia del matrimonio cristiano es un fruto de la Cruz de Cristo, fuente de toda la vida cristiana». La indisolubilidad del matrimonio es «una disposición de la sabiduría divina», que la Iglesia «no tiene poder» para contradecir (n. 1640).

\footnotetext{
$12 \ll$ En efecto, tales ceremonias podrían dar la impresión de que se celebran nuevas nupcias sacramentalmente válidas y como consecuencia inducirían a error sobre la indisolubilidad del matrimonio válidamente contraído».

${ }^{13}$ Vid. especialmente, los nn. 1614, 1615, 1640, 1644, 1647-1651.
} 
Referencias específicas a la situación de los divorciados vueltos a casar se encuentran en algunos números del Catecismo. Así en el n. 1650, siempre dentro del epígrafe titulado «la fidelidad del amor conyugal», el texto resume la doctrina ya recordada por la exh. Familiaris Consortio, pero añade la precisión de que esos fieles, al ponerse en una situación que contradice objetivamente la ley de Dios, «no pueden ejercer ciertas responsabilidades eclesiales» ${ }^{14}$. Sin embargo, esos cristianos deben ser bien atendidos, para que «no se consideren como separados de la Iglesia, de cuya vida pueden y deben participar en cuanto bautizados» ${ }^{15}$.

Además, los nn. 2382 ss. del Catecismo se ocupan del divorcio civil, que se considera una ofensa grave a la ley natural. El n. 2384 advierte con palabras enérgicas que «el hecho de contraer una nueva unión, aunque reconocida por la ley civil, aumenta la gravedad de la ruptura: el cónyuge casado de nuevo se halla entonces en situación de adulterio público y permanente».

En resumen, el Catecismo de la Iglesia católica se encuentra en clara continuidad con el magisterio de Juan Pablo II sobre la situación en la Iglesia de los divorciados vueltos a casar. Por lo que se refiere a la idoneidad de esos fieles en relación con la titularidad de oficios o participación en funciones públicas eclesiásticas, el Catecismo advierte que, dada su situación, ellos no pueden ejercer algunas responsabilidades en la Iglesia, aunque el texto no detalla las funciones de las que resultan excluidos.

\subsection{Carta de la Congregación de la Doctrina de la Fe, de 14-IX-1994: significación social del matrimonio}

El 14 de septiembre de 1994 la Congregación de la Doctrina de la Fe publicó, con aprobación del papa Juan Pablo II, un texto dirigido a los obispos

14 «Hoy son numerosos en muchos países los católicos que recurren al divorcio según las leyes civiles y que contraen también civilmente una nueva unión. La Iglesia mantiene, por fidelidad a la palabra de Jesucristo ("Quien repudie a su mujer y se case con otra, comete adulterio contra aquélla; y si ella repudia a su marido y se casa con otro, comete adulterio": Mc 10,11-12), que no puede reconocer como válida esta nueva unión, si era válido el primer matrimonio. Si los divorciados se vuelven a casar civilmente, se ponen en una situación que contradice objetivamente a la ley de Dios. Por lo cual no pueden acceder a la comunión eucarística mientras persista esta situación, y por la misma razón no pueden ejercer ciertas responsabilidades eclesiales. La reconciliación mediante el sacramento de la penitencia no puede ser concedida más que a aquellos que se arrepientan de haber violado el signo de la alianza y de la fidelidad a Cristo y que se comprometan a vivir en total continencia».

15 Catecismo de la Iglesia católica, n. 1651. 
acerca de la recepción de la comunión eucarística por parte de los fieles divorciados que se han vuelto a casar ${ }^{16}$. La Carta tiene en cuenta especialmente algunas cuestiones, a la vista de nuevos planteamientos (las llamadas «soluciones pastorales») a los que el propio texto responde. Concretamente, se cita la pretensión de que «no sería posible una admisión general de los divorciados vueltos a casar a la comunión eucarística, pero podrían acceder a ella en determinados casos, cuando según su conciencia se consideraran autorizados a hacerlo». En realidad, la carta reafirma las enseñanzas de la Familiaris consortio, doctrina que «no puede ser modificada basándose en las diferentes situaciones» (n. 5).

La enseñanza contenida y recordada en esta Carta de la Congregación de la Doctrina de la Fe no admite que los fieles divorciados vueltos a casar puedan ser titulares de oficios eclesiásticos. Sobre todo porque el documento recuerda que el matrimonio no es una simple situación personal sobre cuya validez se pueda decidir autónomamente según la conciencia individual, sino que tiene una significación social. En efecto, «el matrimonio, en cuanto imagen de la unión esponsal entre Cristo y su Iglesia así como núcleo basilar y factor importante en la vida de la sociedad civil, es esencialmente una realidad pública» (n. 7). Esto implica la necesidad de obedecer a las leyes canónicas, acudiendo también, si fuera el caso, al proceso declarativo de la nulidad matrimonial, pero sin hacer depender, en cambio, esa nulidad de la decisión de la conciencia individual. En efecto, «el consentimiento, sobre el cual se funda el matrimonio, no es una simple decisión privada, ya que crea para cada uno de los cónyuges y para la pareja una situación específicamente eclesial y social. Por lo tanto, el juicio de la conciencia sobre la propia situación matrimonial no se refiere únicamente a una relación inmediata entre el hombre y Dios, como si se pudiera dejar de lado la mediación eclesial, que incluye también las leyes canónicas que obligan en conciencia. No reconocer este aspecto esencial significaría negar de hecho que el matrimonio exista como realidad de la Iglesia, es decir, como sacramento» (n. 8).

2.5. La instrucción «Ecclesiae de mysterio», de 1997: actividades de suplencia y coherencia de vida

El 15-VIII-1997 fue publicada conjuntamente por ocho dicasterios de la curia romana (seis congregaciones y dos consejos pontificios) la instr. Ecclesiae

${ }^{16}$ El texto en AAS 86 (1994) 974-979 y también en www.vatican.va. 
de mysterio, que fue además aprobada en forma específica por el papa Juan $\mathrm{Pa}$ blo II ${ }^{17}$. La instrucción se refiere a «algunas cuestiones acerca de la colaboración de los fieles laicos en el sagrado ministerio de los sacerdotes».

En la parte dedicada a las disposiciones prácticas, después de haber recordado algunos principios teológicos, este documento de la curia se refiere a distintos ámbitos en los que puede plantearse aquella participación de los laicos: el ministerio de la palabra, algunas funciones en el ámbito de la parroquia, los colegios diocesanos («organismos de colaboración en la Iglesia particular»), distintas celebraciones litúrgicas, el ministerio extraordinario de la sagrada comunión, el apostolado en favor de los enfermos, la asistencia a matrimonios, la administración del bautismo, la participación en las exequias eclesiásticas.

Después de haber recordado distintas posibilidades y límites de la colaboración de los laicos en esos campos, la instr. Ecclesiae de mysterio dispone en su art. 13 que, cuando se diera la necesidad objetiva de una suplencia de los sacerdotes, «es deber de la autoridad competente (...) procurar que la persona sea de sana doctrina y ejemplar conducta de vida. Por tanto, no pueden ser admitidos al ejercicio de estas tareas aquellos católicos que no llevan una vida digna, no gocen de buena fama, o se encuentren en situaciones familiares no coherentes con la enseñanza moral de la Iglesia. Además, la persona debe poseer la formación debida para el adecuado cumplimiento de las funciones que se le confían».

La referencia a «situaciones familiares no coherentes con la enseñanza moral de la Iglesia» parece significar que quedan excluidos de los ministerios litúrgicos o tareas auxiliares del gobierno aquellos fieles que, tras obtener el divorcio civil de su matrimonio canónico, hayan vuelto a contraer nuevo matrimonio según las leyes civiles o se encuentren en una situación irregular, al estilo de las expresadas en Familiaris consortio n. 84.

\subsection{Declaración del Consejo Pontificio para los Textos legislativos,} de 24-VI-2000: la aplicación del c. 915 del CIC

Guarda relación con los aspectos canónicos de la situación de los divorciados vueltos a casar una declaración del Consejo Pontificio para los Textos

${ }^{17}$ En AAS 89 (1997) 852-877. 
legislativos acerca del acceso a la comunión eucarística por parte de esos fieles. La declaración fue publicada el 24-VI-2000 por este dicasterio, de acuerdo con la Congregación para la Doctrina de la Fe y con la Congregación para el Culto Divino y la Disciplina de los Sacramentos ${ }^{18}$. Tiene por objeto la interpretación del c. 915 del CIC y, concretamente, si la referencia de la norma a «los que obstinadamente persistan en un manifiesto pecado grave» se aplica a los fieles divorciados que se han vuelto a casar ${ }^{19}$. La Declaración así lo afirma, de manera que esos fieles, al cumplirse las condiciones del c. 915, deberían ser excluidos de la comunión eucarística.

Aparte de las cuestiones que plantea esta declaración, el texto subraya la relevancia social de la situación en la que se encuentran los divorciados que han contraído nuevo matrimonio civil ${ }^{20}$. El escándalo que esa situación provoca, y que es uno de los aspectos morales que el magisterio tiene en cuenta al valorar el acceso al sacramento de la penitencia y a la comunión eucarística por parte de aquellos fieles, es explicado por la Declaración del 2000 como una situación «que mueve a los otros hacia el mal». El escándalo afecta aquí a las disposiciones necesarias para recibir el sacramento de la eucaristía y a la indisolubilidad del matrimonio, y «sigue existiendo aun cuando ese comportamiento, desgraciadamente, ya no cause sorpresa: más aún, precisamente es ante la deformación de las conciencias cuando resulta más necesaria la acción de los pastores, tan paciente como firme, en custodia de la santidad de los sacramentos, en defensa de la moralidad cristiana, y para la recta formación de los fieles».

Haciendo eco a la Familiaris consortio, la declaración del Consejo Pontificio recuerda que los fieles divorciados que se han vuelto a casar deben no sólo arrepentirse y abstenerse de los actos propios de los esposos, sino también remover el escándalo para poder acceder a la comunión eucarística, ya que «el hecho de que tales fieles no vivan more uxorio es de suyo oculto, mientras que su condición de divorciados que se han vuelto a casar es de suyo manifiesta».

18 Cfr. L'Osservatore Romano, 7-VII-2000, 1 y www.vatican.va.

19 El c. 915 del CIC dispone: «No deben ser admitidos a la sagrada comunión los excomulgados y los que están en entredicho después de la imposición o declaración de la pena, y los que obstinadamente persistan en un manifiesto pecado grave».

${ }^{20}$ Federico Aznar explica en su comentario el contexto de la declaración romana y concretamente la historia y las distintas interpretaciones del c. 915: F. R. AZNAR GIL, Divorciados, casados civilmente de nuevo y recepción de la Comunión eucaristica: Declaración del Consejo Pontificio para la Interpretación de los Textos Legislativos (24 junio 2000). Texto y comentario, Revista Española de Derecho Canónico 58 (2001) 261-266, especialmente. 
2.7. Exh. ap. «Sacramentum caritatis», 22-II-2007: eucaristía y matrimonio, derecho y pastoral

El 22 de febrero de 2007, Benedicto XVI publicó la exh. ap. Sacramentum caritatis, dos años después de haberse celebrado en Roma el Sínodo sobre la eucaristía. Este documento pontificio postsinodal dedica un epígrafe a la relación entre los sacramentos de la eucaristía y del matrimonio ${ }^{21}$.

Toda la vida cristiana está marcada por el amor esponsal de Cristo y de la Iglesia. «La eucaristía corrobora de manera inagotable la unidad y el amor indisolubles de cada matrimonio cristiano. En él, por medio del sacramento, el vínculo conyugal se encuentra intrínsecamente ligado a la unidad eucarística entre Cristo esposo y la Iglesia esposa (cfr. Ef 5,31-32). El consentimiento recíproco que marido y mujer se dan en Cristo, y que los constituye en comunidad de vida y amor, tiene también una dimensión eucarística. En efecto, en la teología paulina, el amor esponsal es signo sacramental del amor de Cristo a su Iglesia, un amor que alcanza su punto culminante en la cruz, expresión de sus "nupcias" con la humanidad y, al mismo tiempo, origen y centro de la eucaristía» (n. 27).

A la luz de la relación intrínseca entre matrimonio, familia y eucaristía el documento de Benedicto XVI considera algunos problemas pastorales, especialmente en relación con la unidad y la indisolubilidad del vínculo conyugal. Es en este contexto donde Sacramentum caritatis trata de la situación de los fieles divorciados que se han casado de nuevo, «un problema pastoral difícil y complejo, una verdadera plaga en el contexto social actual, que afecta de manera creciente incluso a los ambientes católicos» (n. 29). La exhortación apostólica confirma la praxis de no admitir a los sacramentos a los fieles que se encuentren en esa situación (praxis y doctrina afirmadas también por el Sínodo de la eucaristía de 2005), «porque su estado y su condición de vida contradicen objetivamente esa unión de amor entre Cristo y la Iglesia que se significa y se actualiza en la eucaristía» (ibid.).

El documento de Benedicto XVI presenta la novedad de una motivación de la praxis y la doctrina de la Iglesia sobre la atención de los divorciados vueltos a casar, enraizada -esa motivación- en el amor esponsal de Cristo por la Iglesia significado en el matrimonio y en la eucaristía. Esta doctrina explica precisamente que los divorciados vueltos a casar no puedan recibir la sagrada

${ }^{21}$ En AAS 99 (2007) 105-180, nn. 27-29. 
comunión mientras no estén dispuestos a vivir conforme al verdadero compromiso matrimonial asumido, o al menos con un estilo de vida que no contradiga el vínculo matrimonial, en el caso de que esos fieles no puedan separarse por razones objetivas.

$\mathrm{Al}$ mismo tiempo, Sacramentum caritatis insiste en la importancia de acoger a estos fieles y señala distintas vías para su participación en la Iglesia: «los divorciados vueltos a casar, a pesar de su situación, siguen perteneciendo a la Iglesia, que los sigue con especial atención, con el deseo de que, dentro de lo posible, cultiven un estilo de vida cristiano mediante la participación en la santa misa, aunque sin comulgar, la escucha de la Palabra de Dios, la adoración eucarística, la oración, la participación en la vida comunitaria, el diálogo con un sacerdote de confianza o un director espiritual, la entrega a obras de caridad, de penitencia, y la tarea de educar a los hijos» (n. 29).

Otra importante apreciación de Benedicto XVI es que donde existan dudas sobre la validez del primer matrimonio debe aprovecharse la oportunidad de acudir a los tribunales eclesiásticos. Y es aquí donde el Pontífice advierte de la relación entre verdad, pastoral y derecho, cuando afirma que «se ha de evitar que la preocupación pastoral sea interpretada como una contraposición con el derecho. Más bien se debe partir del presupuesto de que el amor por la verdad es el punto de encuentro fundamental entre el derecho y la pastoral» (n. 29).

\subsection{Sínodo extraordinario de 2014: evitar la discriminación y promover la participación}

El papa Francisco convocó en 2103, pocos meses después de ser elegido para el pontificado romano, dos asambleas del sínodo de los obispos: una extraordinaria, que se celebró en octubre de 2014 y otra de carácter ordinario, celebrada un año más tarde en octubre de $2015^{22}$. En ambos casos, el Papa quiso promover una amplia reflexión sobre la pastoral familiar.

Veamos en primer lugar lo que se refiere al Sínodo del 2014, dedicado a «los desafíos pastorales de la familia en el contexto de la evangelización». Además de muchas otras cuestiones, este sínodo se ocupó de la situación de los fieles divorciados vueltos a casar. En la relación o informe final votado por los

${ }^{22}$ Sobre las diferencias de convocatoria y composición de las asambleas sinodales, cfr. cc. 345 y 346 del CIC. 
padres sinodales, fue subrayada la necesidad de un adecuado acompañamiento pastoral de esos fieles, «evitando todo lenguaje y actitud que los haga sentir discriminados y promoviendo su participación en la vida de la comunidad» (n. 51) $)^{23}$.

La relatio finalis se hizo eco de las opiniones de los padres sinodales acerca del acceso a los sacramentos por parte de aquellos fieles (en algunas de esas opiniones no fue fácil encontrar plena aceptación del magisterio de Juan $\mathrm{Pa}$ blo II y Benedicto XVI). La relatio finalis vio necesario «profundizar la cuestión, teniendo bien presente la distinción entre situación objetiva de pecado y circunstancias atenuantes, dado que "la imputabilidad y la responsabilidad de una acción pueden quedar disminuidas e incluso suprimidas" a causa de diversos "factores psíquicos o sociales" (Catecismo de la Iglesia Católica, 1735)» ${ }^{24}$.

En ningún lugar del informe final se encuentran referencias a la idoneidad de los divorciados vueltos a casar para oficios o responsabilidades públicas eclesiales.

\subsection{Sinodo ordinario de 2015: examinar posibles exclusiones, promover una mayor integración, evitar el escándalo}

Esta asamblea sinodal de carácter ordinario tuvo lugar un año después de la asamblea extraordinaria del 2014 y fue presentada como la culminación del camino sinodal de reflexión sobre la vocación y misión de la familia.

El documento de trabajo (instrumentum laboris) de la asamblea ordinaria, fechado el 23-VI-2015, se refería a la situación de los divorciados y vueltos a casar intentando promover una mayor integración en la vida de la Iglesia:

$\ll$ Se requiere desde muchas partes que la atención y el acompañamiento respecto a los divorciados vueltos a casar civilmente se orienten hacia una integración cada vez mayor en la vida de la comunidad cristiana, teniendo en cuenta la diversidad de las situaciones de partida. Sin perjuicio de las sugerencias de Familiaris consortio 84, habría que replantearse las formas de exclusión que se practican actualmente en los campos litúrgico-pastoral, educativo y caritativo. Puesto que estos fieles no están fue-

23 El texto italiano de la relatio en AAS 106 (2014) 887-908 (aquí 904 y 905); vid. también www.vatican.va, en la sección correspondiente al sínodo de los obispos.

24 Relatio finalis, n. 52; cfr. también n. 53: AAS 106 (2014) 905. 
ra de la Iglesia, se propone reflexionar acerca de la oportunidad de dejar atrás estas exclusiones. Por otro lado, siempre para favorecer una mayor integración de estas personas en la comunidad cristiana, habría que dirigir una atención específica a sus hijos, dado el papel educativo insustituible de los padres, en razón del preeminente interés del menor» (n. 121) ${ }^{25}$.

Se ve que el instrumentum laboris no consideraba suficientes las llamadas del magisterio precedente a acoger a los fieles divorciados y vueltos a casar, de modo que no dejen de saberse miembros de la Iglesia. El instrumentum laboris daba un paso más, al desear una mayor integración y promover la revisión o replanteamiento de posibles «formas de exclusión» de aquellos fieles de la vida de la Iglesia. Que esto pueda afectar a la titularidad de oficios eclesiásticos es algo que se concluirá después de haber hecho esta revisión; es decir, hace falta un examen específico de la cuestión.

$\mathrm{Al}$ mismo tiempo, en el mismo número 121 del instrumentum laboris se subrayaba la dimensión pastoral y concreta de la participación de estos fieles en la vida de la Iglesia, en el sentido de que se aconsejaba un discernimiento que supiera valorar «la irreversibilidad de la situación y la vida de fe de la pareja en una nueva unión». Los nn. 123 y 125 del documento preparatorio citaban, sin embargo, como referencias claras que debían servir para el discernimiento y valoración de las diversas situaciones, los documentos del magisterio de la Iglesia que ya hemos citado y concretamente: la Familiaris consortio, la carta de la Congregación para la Doctrina de la Fe de 1994 y la Declaración del Consejo Pontificio para los Textos Legislativos del año 2000.

El documento final del sínodo de 2015 menciona la situación de los divorciados vueltos a casar en su tercera parte, capítulo III, titulada: «familia y acompañamiento pastoral» ${ }^{26}$. El n. 84 es más matizado que el instrumentum laboris, pero no evita la equívoca fórmula empleada por este proyecto cuando se refería a «formas de exclusión». En efecto, esta expresión podría evocar una discriminación que en realidad no sea tal, como más adelante advertiré. Por otra parte, la relatio finalis menciona la importancia de evitar cualquier ocasión de escándalo en el proceso de integración de los divorciados vueltos a casar. Esta mención del peligro de escándalo, tan importante en este ámbito, no se

\footnotetext{
${ }^{25}$ El texto del instrumentum laboris y la restante documentación del Sínodo se encuentra en www.vatican.va, en la sección correspondiente al sínodo de los obispos.

${ }^{26}$ Relatio finalis, en L'Osservatore romano, 26/27-X-2015, y también en www.vatican.va.
} 
encontraba en el instrumentum laboris, lo que resultaba sorprendente, sobre todo a la luz del magisterio moral anterior.

He aquí el texto del n. 84 de la relación final del Sínodo de 2015:

«Los bautizados que están divorciados y vueltos a casar civilmente deben integrarse más en las comunidades cristianas según los diversos modos posibles, evitando cualquier ocasión de escándalo. La lógica de la integración es la clave de su acompañamiento pastoral, para que no sólo sepan que pertenecen al Cuerpo de Cristo que es la Iglesia, sino que puedan tener una gozosa y fecunda experiencia de ella. Son bautizados, son hermanos y hermanas, el Espíritu Santo derrama en ellos dones y carismas para el bien de todos».

A continuación ese mismo número 84 explica que la participación de los divorciados y vueltos a casar civilmente «puede expresarse en diversos servicios eclesiales: por ello, es necesario discernir cuáles de las diversas formas de exclusión practicadas actualmente en el ámbito litúrgico, pastoral, educativo e institucional pueden ser superadas (...). Para la comunidad cristiana, cuidar a estas personas no es una debilitación de la propia fe ni del testimonio acerca de la indisolubilidad matrimonial: es más, precisamente la Iglesia expresa su caridad a través de este cuidado» ${ }^{27}$.

En el n. 85 de la relatio finalis, citando Familiaris consortio n. 84, se subraya la importancia del discernimiento entre las distintas situaciones, tarea que corresponde al presbítero, de acuerdo con las enseñanzas del magisterio de la Iglesia y las orientaciones de su obispo. Ese discernimiento supone también

${ }^{27}$ He aquí el texto original italiano del n. 84 de la relatio finalis: «I battezzati che sono divorziati e risposati civilmente devono essere più integrati nelle comunità cristiane nei diversi modi possibili, evitando ogni occasione di scandalo. La logica dell'integrazione è la chiave del loro accompagnamento pastorale, perché non soltanto sappiano che appartengono al Corpo di Cristo che è la Chiesa, ma ne possano avere una gioiosa e feconda esperienza. Sono battezzati, sono fratelli e sorelle, lo Spirito Santo riversa in loro doni e carismi per il bene di tutti. La loro partecipazione può esprimersi in diversi servizi ecclesiali: occorre perciò discernere quali delle diverse forme di esclusione attualmente praticate in ambito liturgico, pastorale, educativo e istituzionale possano essere superate. Essi non solo non devono sentirsi scomunicati, ma possono vivere e maturare come membra vive della Chiesa, sentendola come una madre che li accoglie sempre, si prende cura di loro con affetto e li incoraggia nel cammino della vita e del Vangelo. Quest'integrazione è necessaria pure per la cura e l'educazione cristiana dei loro figli, che debbono essere considerati i più importanti. Per la comunità cristiana, prendersi cura di queste persone non è un indebolimento della propria fede e della testimonianza circa l'indissolubilità matrimoniale: anzi, la Chiesa esprime proprio in questa cura la sua carità». Son mías todas las traducciones de los textos que se incluyen en este ensayo. 
estimular un serio examen de conciencia por parte de los fieles divorciados y vueltos a casar acerca de su situación matrimonial. Bajo el aspecto moral, hay que distinguir entre la situación objetiva de esas personas y la imputabilidad subjetiva.

En conclusión, la relatio finalis pone el acento en facilitar a los divorciados y vueltos a casar su integración en la vida de la Iglesia. Para ello pide revisar lo que en el lenguaje de la relatio serían «exclusiones» («forme di esclusione») en distintas situaciones públicas (litúrgicas, educativas, canónicas, pastorales en general).

Es claro que la relatio finalis del Sínodo ordinario ha supuesto un nuevo planteamiento de la cuestión que aquí tratamos: la idoneidad de los fieles divorciados y vueltos a casar para la titularidad de oficios y funciones públicas en la Iglesia. El Sínodo invita a un examen y verificación de la regulación canónica y litúrgica para comprobar y discernir en qué medida se justifica la «exclusión» de aquellos fieles de las responsabilidades indicadas. Por lo tanto, el nuevo planteamiento no consiste en una apertura general a esas posibilidades, ya que comportaría una grave confusión en la comunidad cristiana acerca de las obligaciones morales derivadas de la indisolubilidad del matrimonio y, además, el propio Sínodo se ha cuidado de recordar que la participación de los divorciados vueltos a casar no puede afirmarse sin valorar el posible escándalo en la comunidad cristiana. Esa integración debe evitar «cualquier ocasión de escándalo».

\subsection{Exh. ap. «Amoris laetitia», 19-III-2016: continuidad con los sinodos de 2014 y 2015}

La exh. ap. del papa Francisco Amoris laetitia evita expresamente dar criterios generales sobre el acceso a los sacramentos por parte de los divorciados que contraen nuevo matrimonio civil y sobre los modos de participación de esos fieles en la vida de la Iglesia. El documento pontificio se expresa en clara continuidad con las reflexiones y propuestas de los sínodos de 2014 y de 2015 sobre la familia, tal como se contienen en las relationes o informes finales de aquellas asambleas romanas. En efecto estos documentos son citados y aprobados en numerosas ocasiones por el papa Francisco ${ }^{28}$.

${ }^{28}$ A la espera de la publicación del documento en AAS, sigo la versión española publicada en www.vatican.va. El hecho de que Amoris laetitia sea un documento más pastoral que doctrinal puede explicar quizás que, a pesar de su amplitud y sus numerosísimas citas, no se encuentre en 
Por lo que se refiere al objeto de nuestro estudio, hay dos aspectos del documento pontificio que conviene destacar.

En primer lugar, una llamada a que los fieles que se encuentren en situaciones matrimoniales irregulares se integren en la vida de la Iglesia. Es una llamada insistente y apasionada por parte del Papa, que tiene diversos acentos: esos fieles no deben ser discriminados, no se encuentran fuera de la Iglesia, deben ser acompañados y participar en la vida comunitaria, hay que examinar su situación moral particular sin rechazos ni condenas generales y en aplicación de un criterio de «misericordia pastoral» ${ }^{29}$.

En este sentido, el papa Francisco acoge expresamente la propuesta del Sínodo de 2015 de valorar qué «formas de exclusión actualmente practicadas en el ámbito litúrgico, pastoral, educativo e institucional pueden ser superadas» (n. 299).

El segundo aspecto que conviene destacar, en relación con los aspectos concretos y limitados de este trabajo, es que la llamada de Amoris laetitia a la integración y participación de los divorciados vueltos a casar en la vida de la Iglesia es básicamente general, sin determinar los aspectos concretos de esa participación. Así, para facilitar la integración de los divorciados con nuevo matrimonio civil en la vida de la Iglesia, el papa Francisco anima a buscar maneras que les lleven «a participar en la vida de la comunidad, sea en tareas sociales, en reuniones de oración o de la manera que sugiera su propia iniciativa, junto con el discernimiento del pastor» (n. 297).

De todas formas, la exhortación apostólica contiene unas palabras del Papa, en tono sencillo y coloquial, más bien restrictivas de la posibilidad de que los divorciados vueltos a casar puedan recibir oficios y ministerios eclesiales: «Obviamente, si alguien ostenta un pecado objetivo como si fuese parte del

\footnotetext{
él una sola referencia a la exh. ap. Sacramentum caritatis de Benedicto XVI, que tuvo el significado especial de haber confirmado las soluciones de Familiaris consortio 84 al problema del acceso a los sacramentos por parte de los divorciados vueltos a casar (en Amoris laetitia solamente hay una referencia indirecta en la nota 329). Tampoco se menciona en el capítulo octavo de Amoris laetitia el documento de la Congregación para la Doctrina de la Fe, de 1994, comentado aquí más arriba. Es un principio general de interpretación teológica el presupuesto de que las enseñanzas de la Iglesia no proceden discontinuamente, a través de saltos bruscos, con determinaciones que anularían la doctrina anterior, sino que se trata más bien de una profundización en la trasmisión de la verdad evangélica, de acuerdo también con las circunstancias de los fieles en las distintas épocas y situaciones. Pienso que es necesario tener en cuenta este criterio armonizador para la recepción de Amoris laetitia, de forma que el documento del papa Francisco no venga considerado aisladamente respecto de las enseñanzas pontificias anteriores.

29 Cfr. especialmente, Amoris laetitia, nn. 243, 246, 291 ss., 296-300, 301-303, 304-306, 307-312.
} 
ideal cristiano, o quiere imponer algo diferente a lo que enseña la Iglesia, no puede pretender dar catequesis o predicar, y en ese sentido hay algo que lo separa de la comunidad (cfr. Mt 18,17). Necesita volver a escuchar el anuncio del evangelio y la invitación a la conversión» (n. 297). Fuera de esta reflexión pastoral, no se encuentra en Amoris laetitia ninguna determinación concreta sobre la relación de aquellos fieles con los cargos y ministerios públicos eclesiásticos.

Amoris laetitia renuncia explícitamente a dar criterios generales que se puedan aplicar indiferenciadamente a las diversas uniones más o menos cercanas al matrimonio ${ }^{30}$. Esto no impide, sino que más bien exige a los intérpretes, una reflexión sobre las razones morales y canónicas que ayuden a explicar los requisitos de acceso a los oficios eclesiásticos, y también hasta qué punto la condición matrimonial sacramental (lo que Amoris laetitia n. 72 llama «don para la santificación y la salvación de los esposos» y verdadera «vocación» divina) es necesaria para mantener la titularidad del oficio o responsabilidad asumida, de forma que la eventual decisión de un nuevo matrimonio civil tras el divorcio comporte el deber de abandonar la tarea que se ejercía.

\section{DE LA REPRESIÓN DE LA INFAMIA (CIC DE 1917)}

\section{A LA VALORACIÓN DEL ESCÁNDALO}

La eventual exclusión de los divorciados vueltos a casar de las funciones públicas eclesiales no se fundamenta actualmente en una determinación general del derecho positivo, ni tampoco en una sanción penal, que no existe para los fieles que se encuentren en esa situación. Sin embargo, en el marco del CIC de 1917 aquella imposibilidad de acceso tenía un planteamiento diferente del actual. En efecto, en el CIC de 1917 la situación de los fieles que se encontraban en una condición de vida irregular desde el punto de vista canónico, venía inscrita en la categoría de la infamia, es decir, una situación que comportaba la pérdida de la buena reputación en la Iglesia, la mala fama. Era una regulación incluida en los cánones del derecho penal canónico. En este sentido el CIC de 1917 distinguía entre infamia de derecho e infamia de hecho ${ }^{31}$. El supuesto

${ }^{30}$ Cfr. nn. 300, 304-306.

31 La primera, la infamia iuris, era determinada por el derecho común, mientras que la segunda, la infamia facti, quería decir la pérdida de buena fama a juicio de los fieles honrados y prudentes, como consecuencia de la comisión de un delito o de malas costumbres. Era el ordinario quien debía juzgar acerca de las circunstancias que comportaban la infamia de hecho, mientras que en el caso de la infamia de derecho la situación de infamia era determinada por la misma ley: cfr. c. 2293 del CIC de 1917. 
de los divorciados vueltos a casar venía configurado como una infamia iuris, como consecuencia del delito de bigamia ${ }^{32}$. La infamia iuris o facti era castigada con una pena vindicativa que comportaba, entre otras consecuencias, la inhabilitación para beneficios y oficios eclesiásticos ${ }^{33}$. Además, los que vivieran públicamente en concubinato debían ser excluidos «de los actos legítimos eclesiásticos» hasta que dieran señales de verdadero arrepentimiento ${ }^{34}$.

En resumen, la situación jurídica de los divorciados vueltos a casar era configurada por el CIC de 1917 en el marco del derecho penal canónico, como un supuesto de infamia iuris que comportaba, entre otras consecuencias, la inhabilitación para el ejercicio de funciones públicas en la Iglesia. Esta reacción penal está ausente por completo en el CIC de 1983, que no incluye ya el supuesto de la infamia dentro de la legislación, salvo algunas normas dirigidas a evitar el peligro de infamia en ciertos $\operatorname{casos}^{35}$. En la legislación actual no existe norma penal ni sanción administrativa que se refiera directa o indirectamente a la situación de los divorciados vueltos a casar. Esto se debe a un cambio de sensibilidad hacia la situación personal de esos fieles por parte de la Iglesia y de la sociedad civil, donde ha influido seguramente la proliferación de las uniones de hecho, los divorcios acompañados de nuevas uniones y en general el fenómeno de la desafección hacia el matrimonio incluido el civil. Ante esa situación tan extendida entre los católicos de no pocas naciones, la reacción penal no es, desde luego, el mejor instrumento para reconducirla.

El número de fieles en situaciones matrimoniales irregulares, y de los católicos divorciados que han contraído matrimonio civil, ha crecido mucho en las últimas décadas, hasta el punto que el magisterio pontificio, como ya hemos recordado, considera este fenómeno social como una verdadera plaga. A la vista de la proliferación de las uniones de hecho y de las situaciones matrimoniales irregulares, mantener la disciplina canónica penal sería por lo menos imprudente e ineficaz. En efecto, la «plaga» social de las situaciones matrimoniales irregulares ha de prevenirse sobre todo a través de la adecuada for-

32 El c. 2356 del CIC de 1917, situado dentro del título XIV, dedicado a «los delitos contra la vida, la libertad, la propiedad, la buena fama y las buenas costumbres», calificaba de infames a los bígamos, esto es, a quienes existiendo un vínculo conyugal que lo impedía, atentaban contraer matrimonio aunque sólo fuese civil.

33 Cfr. c. 2294 del CIC de 1917.

${ }^{34}$ Cfr. c. $2357 \$ 2$ del CIC de 1917.

${ }^{35}$ Cfr. los cc. 1048, $1352 \S 2,1548 \S 2.2^{\circ}$ del CIC de 1983. 
mación de los fieles, la profundización en la pastoral familiar, la difusión del evangelio sobre el matrimonio y la familia. De todos modos, la ausencia de reacción penal es compatible con oportunas previsiones para defender la comunión eclesial frente al peligro de indiferentismo, escándalo o confusión de los fieles, que es donde entra precisamente la cuestión de la idoneidad o no para la titularidad de oficios eclesiásticos de los fieles que se encuentren en situaciones matrimoniales irregulares.

En particular, la cuestión del escándalo debe ser oportunamente perfilada. Desde luego esta figura no debe confundirse con la mayor o menor reacción de sorpresa o perplejidad ante los avatares de la vida en pareja y de las familias, ya que ésa es una cuestión que tiene que ver sobre todo con las reacciones psicológicas ante los cambios sociales. El escándalo no es una cuestión estadística, en el sentido de que existiría si fuesen muchos los que se molestaran o sorprendieran ante el cambio de los estilos de vida de los hombres y mujeres de nuestro tiempo, y no existiría en caso contrario. Son compatibles el acostumbramiento, la indiferencia e incluso la aceptación social de formas de convivencia opuestas al matrimonio con la existencia del escándalo como realidad teológica ${ }^{36}$. Es más, las situaciones generalizadas de relativismo o ignorancia no excusarían, sino que deberían alimentar, una paciente y profunda catequesis sobre la naturaleza del matrimonio y la familia ${ }^{37}$.

Según la concepción clásica, el escándalo es un dicho, un hecho o una omisión que es ocasión de ruina espiritual para el prójimo ${ }^{38}$. En este sentido puede referirse también a situaciones personales permanentes que confunden y hacen daño a los fieles. El Catecismo de la Iglesia Católica trata del escándalo con ocasión del quinto mandamiento del Decálogo y el respeto de la dignidad de las personas. Dice el n. 2284 del Catecismo: «El escándalo es la actitud o el comportamiento que induce a otro a hacer el mal. El que escandaliza se convierte en tentador de su prójimo. Atenta contra la virtud y el derecho; puede ocasionar a su hermano la muerte espiritual. El escándalo constituye una falta grave si, por acción u omisión, arrastra deliberadamente a otro a una falta grave». Es tanto más dañino cuanto más débiles sean quienes lo padecen

${ }^{36}$ Cfr. G. TRevisan, I divorziati risposati possono assumersi delle responsabilità nella vita della Chiesa?, Quaderni di Diritto Ecclesiale 6 (1993) 254.

37 Esta línea argumental está presente en la Declaración del Consejo Pontificio para los Textos Legislativos de 24-VI-2000, que ya ha sido citada.

38 Cfr. S. Th. II-II, q. 43, art. 1: «...definiatur esse dictum vel factum minus rectum praebens occasionem ruinae». 
(n. 2285) y «puede ser provocado por la ley o las instituciones, por la moda o por la opinión», de modo que «se hacen culpables de escándalo quienes instituyen leyes o estructuras sociales que llevan a la degradación de las costumbres y a la corrupción de la vida religiosa, o a "condiciones sociales que, voluntaria o involuntariamente, hacen ardua y prácticamente imposible una conducta cristiana conforme a los mandamientos del Sumo legislador" (Pío XII, Mensaje radiofónico, 1 junio 1941)» (n. 2286).

En este sentido, comportamientos como una indebida promoción de los fieles divorciados y vueltos a casar en las comunidades cristianas podrían resultar objetivamente escandalosos, por las negativas consecuencias de indiferentismo hacia las exigencias de la ley moral.

La teología moral distingue tradicionalmente el escándalo real, el farisaico y el de los débiles ${ }^{39}$. Solamente el primero supone una situación objetiva que es ocasión de ruina espiritual para los fieles. En cambio, el escándalo farisaico existe sólo en la mente de algunas personas, a causa de su malicia, como en el caso de los fariseos que condenaron a Jesús invocando la ley judía. Por su parte, el escándalo de los débiles o pusilánimes afecta a personas que resultan confundidas por una situación de suyo no escandalosa, normalmente a causa de su fragilidad o ignorancia. Mientras el escándalo farisaico puede ser ignorado, por no constituir propiamente ocasión de ruina espiritual en los fieles, el de los débiles debe ser evitado prudentemente, aunque la acción supuestamente escandalosa sea realmente legítima. Pues bien, si el escándalo de los débiles ha de evitarse en lo posible (a pesar de no tratarse propiamente de una situación escandalosa), cuánto más el escándalo que produce realmente en la comunidad cristiana la situación de los divorciados vueltos a casar. La influencia negativa de la proliferación de estas situaciones en las comunidades parroquiales, en las asociaciones de fieles y en los movimientos eclesiales puede ser realmente demoledora de las costumbres cristianas, en el caso de que los pastores o responsables se dejen llevar abiertamente por el indiferentismo o incluso lleguen a justificar la situación de los divorciados vueltos a casar, diciendo, por ejemplo, que son esos fieles los que están en condiciones de promover, a partir de su experiencia dolorosa, una verdadera pastoral familiar...

39 Recuerda esta distinción G. TREVISAN, I divorziati risposati, 254. Vid., por ejemplo, I. AdEvA MARTín, Escándalo, en Gran Enciclopedia Rialp, VIII, Rialp, Madrid 1972, 741-743. 


\section{REFLEXIONES SOBRE VERDAD, JUSTICIA Y MISERICORDIA}

Cuando se habla de la integración en la Iglesia de los divorciados que se han vuelto a casar, es necesario profundizar en las razones que eventualmente no les permitan ejercer funciones públicas.

Ante todo, la razón de la eventual exclusión de esos fieles respecto a los oficios eclesiásticos no es su incapacidad sino la falta de idoneidad, como advertimos al comienzo de este estudio. La idoneidad es una categoría general que emplea el derecho administrativo canónico y que incluye una valoración objetiva, por parte de la autoridad, acerca de si el candidato al oficio o a la responsabilidad de que se trate posee los requisitos necesarios.

El Sínodo de la familia de 2015 y la exh. ap. Amoris laetitia han insistido en la necesidad de examinar las distintas situaciones en las que pueden encontrarse los divorciados vueltos a casar, aunque en rigor esa insistencia no es nueva, pues ya se encontraba en la Familiaris consortio de 1981. Es cierto que hay casos en los que el divorcio podría no ser culpable y haber sido motivado ante todo por la mala conducta de uno de los cónyuges; o que se hubiera valorado especialmente la eventual protección que la legislación civil prestaría al cónyuge inocente en tal caso. Además, la celebración de un nuevo matrimonio civil podría haberse debido a distintas motivaciones, sobre todo al considerar la mejor atención de los hijos, e incluso haberse celebrado con ignorancia o ideas confusas sobre la doctrina de la Iglesia al respecto. Todo esto es verdad y tiene claras implicaciones sobre el juicio moral concreto que merezcan estas situaciones.

Ahora bien, la situación de esos fieles es objetiva, es una «pública contradicción con la comunión eclesial» ${ }^{40}$. Es decir, se encuentran en una situación pública y estable que contradice la indisolubilidad del matrimonio y la relación intrínseca entre vida conyugal y verdadero matrimonio. Es una de las llamadas «situaciones de manifiesta indisposición moral», como consecuencia de un comportamiento externo y grave manifiestamente contrario al evangelio ${ }^{41}$.

${ }^{40}$ M. A. ORTIZ, También llamados a la santidad. La pastoral de los fieles divorciados vueltos a casar civilmente, en N. Álvarez DE LaS Asturias (ed.), En la salud y en la enfermedad. Pastoral y derecho al servicio del matrimonio, Cristiandad, Madrid 2014, 137. El estudio ha sido también publicado en italiano en C. J. ERrÁZuriz M. - M. A. OrTIZ (eds.), Misericordia e diritto nel matrimonio, Edusc, Roma 2014, 99-129. Cfr. también F. R. AZNAR GIL, El debate sinodal (2014) sobre la situación eclesial de los fieles divorciados y casados de nuevo civilmente, Apollinaris 87 (2014) 455.

${ }^{41} \mathrm{La}$ terminología de «situaciones de manifiesta indisposición moral» fue empleada por Juan Pablo II en la enc. Ecclesia de Eucharistia, 17-IV-2003, AAS 95 (2003) 433-475, n. 37. Un amplio estudio sobre la relevancia canónica y pastoral de esta doctrina en A. S. SáNCHEZ GIL, La pastorale dei fedeli in situazioni di manifesta indisposizione morale, Ius Ecclesiae 26 (2014) 555-578. 
Ocurre que, más allá del juicio que merezca su vida pasada, algunos fieles divorciados que se han vuelto a casar, al tiempo que sienten la necesidad de conversión o incluso piden los sacramentos y pretenden ser recibidos en la Iglesia a pleno título, perseveran en la voluntad actual de vivir como esposo y esposa sin serlo realmente; en algunos casos reclaman también que su situación sea reconocida y aceptada por la comunidad diocesana o parroquial. Naturalmente, estas actitudes plantean a las Iglesias locales un abierto desafío. Son casos bien diferentes de aquellos en los que los fieles divorciados vueltos a casar, a la vista de la imposibilidad de separarse (principalmente, pero no sólo, para no perjudicar a los hijos), deciden abstenerse de los actos propios de los esposos y procuran evitar el escándalo que produce su situación ante otros fieles. Esta última situación puede deberse a una profunda conversión de los fieles, al dejar de creer que la segunda unión y el tiempo pasado lo hayan solucionado todo.

En esta materia es necesario tener bien presente la doctrina moral acerca de los actos intrínsecamente malos por su objeto. Esta doctrina tradicional, expresada por ejemplo en el Catecismo de la Iglesia Católica, nn. 1749-1756, fue recordada formalmente por san Juan Pablo II en su encíclica Veritatis splendor, de 6-VIII-1993. En este importante documento el Pontífice enseñaba que los preceptos negativos del decálogo, entre los que se cuenta la prohibición del adulterio y de los actos sexuales realizados fuera del legítimo matrimonio, no admiten excepción alguna en su sanción moral ${ }^{42}$, tampoco cuando la buena intención podría justificarlos por compasión o cuando se pudiera creer falsamente que el paso del tiempo podría dar razón a comportamientos consolidados. No basta atender a las consecuencias ni limitarse a ponderar las buenas intenciones para concluir sobre la moralidad de los actos humanos.

La Veritatis splendor describe y critica algunas doctrinas éticas teleológicas, según las cuales el comportamiento sería recto si produjera un estado de cosas que mejorase la situación anterior para todos los interesados, ya que este planteamiento puramente pragmático no puede aceptarse contra la verdad de las situaciones personales ${ }^{43}$. La experiencia de católicos que hayan podido rehacer su vida, después de un fracaso matrimonial, a través de una nueva relación amorosa en la que afirman haber encontrado serenidad y equilibrio después de una época atormentada, no siempre alude a situaciones sublimes imaginarias sino que puede corresponder a la realidad. Sin embargo, la verdad no puede ser ig-

42 En AAS 85 (1993) 1133-1228, nn. 52, 67, passim.

43 Cfr. Enc. Veritatis splendor, n. 74. 
norada, por dura que pueda parecer. Ciertamente impresiona la pretendida elección sin alternativas entre felicidad personal y obediencia a la ley de Dios, pero es imprescindible valorar si la primera unión fue un verdadero matrimonio. Lo contrario supone ceder a la tentación de disimular las cosas y mirar hacia otro lado sin resolver el problema de fondo, que no es otro que el de la «conyugalidad», como explica el Cardenal Velasio De Paolis ${ }^{44}$. Ni siquiera la realidad de los hijos habidos después de la segunda unión (que naturalmente deben ser bien atendidos y educados, en todo caso) puede aconsejar y menos obligar a vivir maritalmente con quien no es el propio cónyuge. Por otra parte, la indisolubilidad, la verdad del principio (Mt 19,8), no es una ley que se impone desde fuera incluso a costa de la felicidad de los cónyuges, sino un verdadero don divino que configura desde dentro el matrimonio y hace a los esposos capaces del don de sí en mutua y perpetua fidelidad, a pesar de los fracasos personales.

Experiencias como las de católicos que se han mantenido fieles a los compromisos matrimoniales asumidos sin ceder a la tentación de una nueva unión consoladora (y que han confiado en la Iglesia y su magisterio), el ejemplo heroico de los mártires, los momentos históricos en los que la autoridad eclesiástica ha sabido defender la indisolubilidad del matrimonio a pesar de amenazas y rupturas promovidas por los poderosos de este mundo, deberían hacer reflexionar frente al peligro de legitimar a toda costa relaciones afectivas y sentimentales, incluso al margen del evangelio.

Me parece siempre necesaria una reflexión sobre las relaciones entre verdad, justicia y misericordia, teniendo a la vista, al mismo tiempo, que el matrimonio no es una relación personal privada, sino que tiene una dimensión social y eclesial de primer orden ${ }^{45}$. No son precisamente diplomáticas las palabras del Catecismo de la Iglesia católica cuando recuerda que «el hecho de contraer una nueva unión, aunque reconocida por la ley civil, aumenta la gravedad de la ruptura: el cónyuge casado de nuevo se halla entonces en situación de adulterio público y permanente» (n. 2384). En efecto, ¿`cómo desconocer la relevancia comunitaria de esta situación? La respuesta de la Iglesia a la situación de los

${ }^{44}$ Cfr. V. De Paolis, Los divorciados vueltos a casar y los sacramentos de la eucaristía y de la penitencia, en R. Dodaro (ed.), Permanecer en la verdad de Cristo. Matrimonio y comunión en la Iglesia católica, Cristiandad, Madrid 2014, 210.

45 Sobre la significación pública y social del sacramento del matrimonio, cfr. J. RATZINGER, Introducción, en CONGREGaCión PARA La DOCTRINA DE la FE, Sobre la atención pastoral de los divorciados vueltos a casar. Documentos, comentarios y estudios, trad. esp., Palabra, Madrid 2000, 23; y M. F. POMPEDDA, Problemáticas canónicas, ibid., 74 y 75. 
divorciados vueltos a casar no es un castigo ni responde a un rigorismo que sacrificaría la felicidad personal, sino que atiende a una realidad que no por extendida deja de ser muy grave para la vida cristiana. La proliferación de estas situaciones contribuye a consolidar comportamientos cada vez más arraigados y a su vez tienden a configurar estructuras de pecado, que hacen cada vez más difícil el conocimiento práctico de la verdad moral y la asimilación de las consecuencias personales y sociales del seguimiento de Jesucristo en un ámbito tan delicado e importante como el matrimonio y la familia ${ }^{46}$.

\section{Algunos OFICIOS ClaRAMENTE EXCLUIDOS}

\subsection{En el ámbito del «munus regendi» y el ejercicio de la potestad de régimen}

Entre los oficios de los que pueden ser titulares los fieles laicos, hay algunos que tienen especial relevancia por la naturaleza de las funciones unidas al cargo, o también por la exigencia de un especial testimonio de vida del titular.

La posibilidad de que un laico pueda ejercer el oficio de juez está prevista por el CIC, según la norma del c. $1421 \$ 2$ para el caso de que la conferencia episcopal del territorio así lo admita. Pero el Motu Proprio Mitis iudex del papa Francisco, de 15-VIII-2015, ha ampliado la previsión del CIC, al establecer en el nuevo c. $1673 \$ 3$ que «las causas de nulidad del matrimonio quedan reservadas a un colegio de tres jueces. Éste debe ser presidido por un juez clérigo y los demás jueces pueden ser también laicos» ${ }^{47}$. Según esta norma, no se requiere ya la autorización de la conferencia episcopal para que los laicos puedan ser jueces en tales casos.

De todos modos, para ser titular del oficio de juez es necesaria, entre otras condiciones, la buena fama ${ }^{48}$. La importancia singular del oficio de juez deriva

${ }^{46}$ Cfr. Juan Pablo II, exh. ap. Reconciliatio et poenitentia, 2-XII-1984, n. 16 sobre la distinción entre pecado personal y pecado social. Como dice el Cardenal Robert Sarah, «la multiplicación de los divorcios y los posteriores matrimonios son pecados que provocan situaciones sociales o instituciones contrarias a la bondad divina. Las "situaciones de pecado" creadas de este modo son expresión y consecuencia de los pecados personales. Inducen a otros a cometer ese mal»: R. SARAH, Dios o nada. Entrevista sobre la fe con Nicolas Diat, trad. esp., Palabra, Madrid 2015, 301. Sigo el texto publicado en www.vatican.va, a la espera de la publicación en AAS.

${ }^{48}$ Cfr. c. $1421 \S 3$, instr. Dignitas connubii, art. $43 \$ 3$. La instrucción fue publicada por el Consejo Pontificio para los Textos Legislativos el 25-I-2005, habilitado mediante decreto pontificio de 4-II-2003, según consta en su preámbulo. 
de su participación en una de las manifestaciones más significativas de la potestad de régimen, que se distingue en legislativa, ejecutiva y judicial (c. $135 \$ 1$ del CIC). Por lo tanto, la función del juez no es meramente técnica (aunque desde luego requiere una exigente preparación profesional), sino que comporta la titularidad de una de las manifestaciones de la sacra potestas en la Iglesia y además por oficio, es decir, con la estabilidad del cargo asumido. Semejante responsabilidad requiere más que unos estudios previos o el cumplimiento de unos mínimos requisitos de selección e idoneidad. Por todos estos motivos debe excluirse que los divorciados vueltos a casar puedan ser jueces eclesiásticos ${ }^{49}$.

Dentro del ámbito de los tribunales de la Iglesia queda naturalmente excluido de los divorciados que contraen nuevo matrimonio civil el oficio de defensor del vínculo. La contradicción entre la función propia de este cargo con la situación personal de esos fieles resulta evidente ${ }^{50}$. Además, se exige expresamente aquí la buena fama del titular, al igual que ocurre con el oficio de promotor de justicia, con el moderador de la cancillería del tribunal y con los demás notarios $^{51}$.

Otro oficio claramente excluido es el de canciller. El canciller de la curia debe constituirse en cada diócesis y viene a ser el notario principal, cuya función es redactar, expedir y custodiar las actas de la curia; su escritura o firma da fe pública de los actos jurídicos ${ }^{52}$. No pocas veces el oficio de canciller es desempeñado por la misma persona nombrada moderador o secretario general de la curia diocesana y en este caso debe tratarse de un sacerdote (cfr. c. 473 $\$ 2$ ); pero no se excluye que, fuera de ese caso, el oficio pueda ser confiado a un fiel laico. Para la promoción al cargo de canciller es requerida formalmen-

49 Federico AZNAR (El debate sinodal [2014] sobre la situación eclesial de los fieles divorciados y casados de nuevo civilmente, Apollinaris 87 [2014] 462) considera, sin embargo, que no hay razones intrínsecas, aunque sí de prudencia pastoral, que impidan que los divorciados vueltos a casar puedan «desempeñar algunos cargos en el tribunal eclesiástico, como juez, defensor del vínculo o abogado, ya que no están privados de la "buena fama"». Me parece ver aquí una cierta contradicción entre negar la idoneidad de aquellos fieles para ser miembros de un Sínodo diocesano o de un Consejo pastoral «porque reclaman la necesaria plenitud de comunión y testimonio cristiano» (ibid., 461) y reconocer, en cambio, la idoneidad para ser juez eclesiástico, que requiere una responsabilidad mayor por el ejercicio de la sacra potestas. A mi juicio, estos cargos son claros ejemplos de funciones públicas que exigen especial ejemplaridad. En el caso del juez, además, resultaría paradójico que quien no cumple la «legalidad» eclesial (aunque no se trata solamente de un problema de legalidad) sea precisamente quien se encargue de aplicarla por oficio.

${ }^{50}$ Cfr. c. 1432 del CIC; instr. Dignitas connubii, art. 56.

${ }^{51}$ Cfr. respectivamente, los cc. 1435 y $483 \$ 2$ del CIC; instr. Dignitas connubii, arts. 54 y 63.

52 Cfr. cc. $474,482 \$ 1,483 \$ 1$. 
te la buena fama del candidato (c. $483 \$ 2$ del CIC). Por ese motivo, y atendida también la relevancia del oficio de canciller por su estrecha relación con los actos del gobierno diocesano, debe excluirse, a mi juicio, que el cargo sea atribuido a un fiel divorciado y vuelto a casar. Entiéndase bien: la razón de que esa persona no deba ser nombrada no consiste solamente en que el canciller sea un cargo importante en la diócesis, sino en que la situación de aquélla contradice la razón de ejemplaridad que debe ser exigida especialmente en los gobernantes y quienes colaboran estrechamente con ellos. El hecho de que la situación matrimonial de un gobernante sea públicamente irrelevante en tantos países, no significa que lo sea en la Iglesia, verdadera comunión espiritual que promueve y alimenta la salus animarum. La salvación de las almas reclama la ejemplaridad de los pastores y de quienes les ayudan directamente.

Las mismas razones que planteo en relación con el canciller son válidas, a mi juicio, a propósito del ecónomo diocesano. Este oficio, al que corresponde la gestión ordinaria de los bienes de la diócesis y de los gastos necesarios, puede ser atribuido a un fiel laico. El derecho exige ante todo en el ecónomo las condiciones de ser «verdaderamente experto en materia económica y de reconocida honradez» (c. $494 \$ 1)$. Podría pensarse que estas condiciones nada tienen que ver con la condición matrimonial del candidato, pero la relevancia de sus funciones y la razón de ejemplaridad que viene aquí exigida por su cercanía con un ámbito del gobierno ordinario de la diócesis, desaconsejan abiertamente que este oficio pueda ser atribuido a un fiel que después de divorciarse haya contraído un matrimonio civil y permanezca en esa unión.

Además de los oficios unipersonales, se plantea la cuestión de la participación de los divorciados vueltos a casar en los colegios de la organización diocesana y parroquial que están abiertos a los laicos, entre los que destaca el caso del Consejo pastoral, diocesano y parroquial, allí donde esté constituido. En la regulación del Consejo pastoral de la diócesis el CIC requiere expresamente que lo compongan fieles «que estén en plena comunión con la Iglesia católica, (...) sobre todo laicos»; además, esos fieles deben destacar «por su fe segura, buenas costumbres y prudencia» (c. $512 \$ \$ 1$ y 3 ). Si la exigencia de la plena comunión puede interpretarse referida a los no católicos, las demás condiciones de la norma citada hacen imposible, a mi juicio, la promoción para este colegio de los fieles divorciados que se han vuelto a casar, pues no destacan objetivamente por su fe segura ni por sus buenas costumbres. Lo mismo vale para el Consejo pastoral parroquial, con mayor motivo incluso, pues la condición de estos fieles es normalmente más conocida. 


\subsection{En el ámbito de la función de enseñar}

Fuera del ámbito de los oficios relacionados más o menos ampliamente con distintos aspectos de la potestad sagrada de gobierno, hay oficios que tienen una importante vinculación con la función de enseñar en la Iglesia, con el munus docendi. Aquí cabría mencionar especialmente el caso de los profesores de religión católica en centros de enseñanza públicos, así como el supuesto de docentes en universidades católicas y eclesiásticas, en la medida en que la autoridad eclesiástica (la Santa Sede o el obispo diocesano) tengan reconocido el derecho a nombrarlos o, al menos, de participar en el nombramiento. Es en este ámbito donde se plantean mayores tensiones, también por los reflejos civiles de situaciones de falta de idoneidad de esas personas para la función que desempeñan, especialmente cuando se trata de laicos que, habiendo sido considerados idóneos en el momento de su promoción y nombramiento, acuden más tarde al divorcio civil y formalizan una segunda unión ${ }^{53}$. En tales casos, la autoridad eclesiástica remueve de su cargo a esas personas, que a veces acuden a los tribunales civiles alegando haber sido lesionadas en sus derechos.

Los reflejos de estas situaciones en los ordenamientos civiles varían bastante según la legislación de cada país y la mayor o menor amplitud con que se reconoce la libertad de la Iglesia de establecer las condiciones de selección y nombramiento. Al mismo tiempo, pueden prevenirse antes de que se firme el contrato definitivo, si se hace saber a la persona interesada que el divorcio y posterior matrimonio civil es una de las causas previstas para la remoción administrativa del encargo recibido. Pero más allá de las consecuencias del problema en el ámbito civil, aquí interesa principalmente la cuestión canónica de fondo: ¿es idóneo como profesor de religión católica o docente en una facultad eclesiástica un fiel que se ha divorciado y vuelto a casar? A mi juicio, la respuesta a esta pregunta no puede ser sino negativa. La autoridad que procede al nombramiento o participa en el proceso de selección no debería dar el visto bueno a fieles que se encuentren en esa situación; en el caso de que esa situación se haya dado con posterioridad al nombramiento, la autoridad se vería legitimada para proceder a la remoción canónica del titular de ese encargo, ya que en tal caso la situación de escándalo sería más grave si la autoridad no tomase ninguna medida administrativa ${ }^{54}$.

${ }^{53}$ Cfr. J. OTADUY, Relación jurídica de los profesores de religión en España. La dimensión canónica, Ius Canonicum 46 (2006) 445-489; IDEM, El mandato de la autoridad eclesiástica para enseñar disciplinas teológicas, Folia theologica et canonica III, 27/17 (2014) 99-122.

${ }^{54}$ Sobre la remoción del oficio, cfr. cc. 192-195 del CIC. 
En efecto, la enseñanza de la teología o de la religión católica tiene dos aspectos distintos, pero no plenamente separables. El primero de ellos es la profesionalidad con la que debe llevarse a cabo esa enseñanza, de acuerdo con el carácter científico de esas materias según el currículo académico. Pero al mismo tiempo, esa enseñanza no es aséptica ni tiene un carácter tan neutro que pueda impartirse al margen de una identificación personal o al menos un respeto que no contradiga su contenido. Se entiende así que el c. $803 \$ 2$, referido a la escuela católica, exija que los profesores deben destacar «por su recta doctrina e integridad de vida» y que el c. $804 \$ 2$ establezca que es deber del ordinario del lugar cuidar de que los profesores de religión, también en el caso de las escuelas no católicas, «destaquen por su recta doctrina, por el testimonio de su vida cristiana y por su aptitud pedagógica». Aún más, el c. 805 dispone que «El ordinario del lugar, dentro de su diócesis, tiene el derecho a nombrar o aprobar los profesores de religión, así como de remover o exigir que sean removidos cuando así lo requiera una razón de religión o moral». Aparte de estos cánones, que se refieren a las escuelas, semejantes criterios de profesionalidad, competencia y moralidad se aplican también a los profesores universitarios en universidades católicas y eclesiásticas: «La autoridad competente según los estatutos debe procurar que, en las universidades católicas, se nombren profesores que destaquen, no sólo por su idoneidad científica y pedagógica, sino también por la rectitud de su doctrina e integridad de vida; y que, cuando falten tales requisitos, sean removidos de su cargo, observando el procedimiento previsto en los estatutos» ${ }^{55}$.

De este modo, allí donde la autoridad eclesiástica intervenga en la selección y nombramiento de profesores, bien porque se trate de centros de la misma Iglesia, bien porque las leyes estatales así lo reconozcan, tiene el derecho y el deber de velar por la adecuación entre el contenido del mensaje y el testimonio personal del docente.

\subsection{En el ámbito de la función de santificar}

Por seguir con el esquema teológico y canónico de los tria munera Christi et Ecclesiae, se puede valorar también el ámbito del munus sanctificandi. En cuanto a la posible titularidad de ministerios litúrgicos estables u ocasionales por

${ }^{55}$ C. $810 \$ 1$ del CIC; cfr. también el c. 818 , que aplica el c. 810 también a las universidades y facultades eclesiásticas. 
parte de los divorciados vueltos a casar, el directorio de pastoral familiar publicado por la Conferencia episcopal italiana en 1993 dice que «es evidente que no pueden desempeñar en la comunidad eclesial aquellos servicios que exigen una plenitud de testimonio cristiano, como son los servicios litúrgicos y en particular los de lector, el ministerio de catequista, el oficio de padrino para los sacramentos. (...). En cambio, no hay razones intrínsecas para impedir que un divorciado vuelto a casar haga de testigo en la celebración del matrimonio, aunque la sabiduría pastoral intentará evitarlo, por el claro contraste que existe entre el matrimonio indisoluble del que esa persona da testimonio y la situación de violación de la misma indisolubilidad que vive personalmente» ${ }^{56}$.

En efecto, los ministerios litúrgicos no comportan simplemente la actividad material de distribuir la sagrada comunión o leer la Sagrada Escritura, sino que por definición exigen una implicación personal con lo que se representa y se proclama. De todos modos, hay ministerios como los de comentador o cantor $($ c. $230 \$ 2)$ que no tienen esa especial proximidad con la palabra y el sacramento, de modo que pueden ser desempeñados por los divorciados vueltos a casar. También pueden darse en este ámbito situaciones de necesidad por falta de personas, en cuyo caso no habría obstáculos para que estos fieles interviniesen en la acción litúrgica con el ejercicio de los correspondientes ministerios ${ }^{57}$.

Por lo que se refiere a la actuación de los divorciados vueltos a casar como padrinos del bautismo y de la confirmación, las normas vigentes excluyen esa posibilidad, ya que exigen que el candidato «lleve una vida congruente con la fe y con la misión que va a asumir» ${ }^{58}$.

\section{OFICIOS Y MINISTERIOS DESACONSEJADOS POR RAZONES DE PRUDENCIA. CASOS DUdOSOS}

Además de algunos casos en los que resulta clara la falta de idoneidad para el oficio de los divorciados vueltos a casar, hay otros supuestos en los que podrían venir excluidos por razones de prudencia, e incluso existen supuestos más bien dudosos, que habrán de resolverse en el caso concreto.

\footnotetext{
${ }^{56}$ Ufficio Nazionale per la pastorale della famiglia, Direttorio di Pastorale Familiare, 1993, actualizado el 21-VII-1999, n. 218, en www.chiesacattolica.it/documenti, también citado en H. FrANCESCHI, Divorziati risposati e nullità matrimoniale, en H. FRANCESCHI - M. A. ORTIZ (a cura di), Ius et matrimonium. Temi di diritto matrimoniale e processuale canonico, Edusc, Roma 2015, 126 y 127. $57 \mathrm{Al}$ principio de necesidad se refiere G. TREVISAN, I divorziati risposati, 258 y ss.

${ }^{58}$ Cfr. cc. $874 \$ 1.3^{\circ}$ y $893 \$ 1$.
} 
La función de abogado o procurador ante los tribunales de la Iglesia no equivale a la titularidad de un oficio en sentido propio, sino que se trata de personas que asumen respectivamente la asistencia técnica a quien es parte en un juicio y su representación procesal. Los abogados y procuradores deben ser de buena fama, según el c. 1483, y en todo caso, el abogado debe ser aprobado por el obispo ${ }^{59}$. Además, según el c. 1487 , «tanto el procurador como el abogado pueden ser rechazados por el juez mediante decreto, tanto de oficio como a instancia de parte, pero siempre por causa grave» ${ }^{60}$.

Es dudoso que el obispo pueda no dar su aprobación a un abogado, o bien que el juez pueda apartar al abogado o al procurador, con el único motivo de que esa persona está divorciada y ha vuelto a contraer matrimonio civil. No sólo porque no se trata de verdaderos oficios eclesiásticos, sino también porque su función propia no implica un testimonio de vida estrictamente vinculado a ella. A mi juicio, la buena fama requerida por la legislación se refiere aquí ante todo, aunque no exclusivamente, a la honradez y competencia profesionales de los abogados y procuradores, que es lo que debe valorarse principalmente, hasta el punto que incluso el obispo puede permitir que actúen ante los tribunales eclesiásticos abogados no católicos (c. 1483) ${ }^{61}$.

En el ámbito del munus docendi surgen dudas sobre la actividad catequética, por la que «mediante la enseñanza de la doctrina y la práctica de la vida cristiana», se busca que la fe de los fieles «se haga viva, explícita y operativa» (c. 773). En efecto, la actividad catequética tiene distintas manifestaciones y no tiene el mismo alcance, por ejemplo, cuando se desarrolla en la intimidad familiar o en la parroquia, o cuando se realiza en la parroquia con nombramiento del párroco o sin él. Cuando sea necesario un nombramiento que sitúe a esa persona en una posición públicamente destacada, por ejemplo al frente de un oficio catequético, no resulta prudente confiar ese encargo a un divorciado o a una divorciada que se hayan vuelto a casar, pues podría surgir la duda acerca de un posible respaldo a su situación personal a través de ese

59 Cfr. también instr. Dignitas connubii, art. 105.

60 La instr. Dignitas connubii, art. 109, añade que ese decreto debe ser motivado.

61 Sin embargo, una respuesta de la Signatura Apostólica fechada el 12-VII-1993, dada para un caso particular, declaró que un divorciado vuelto a casar no debe ser admitido como abogado en causas matrimoniales, ya que la intervención en tales procesos requiere una recta doctrina sobre el matrimonio, que también debe manifestarse en la vida personal. Cfr. el texto y un comentario a esa respuesta particular en R. L. BURKE, Commentarium de responsione in casu particulari de inidoneitate advocatorum qui in unione irregulari vivunt ad patrocinium in causis nullitatis matrimonii exercendum, Periodica de re canonica 82 (1993) 699-708. 
nombramiento, como si el divorcio y posterior matrimonio civil no tuvieran relevancia en la transmisión pública y comunitaria de la doctrina cristiana. El testimonio personal de vida no se agota ciertamente en la formalidad del matrimonio externamente «bien avenido», pero sería ingenuo no valorar la posible influencia de aquella situación en la comunicación de la enseñanza cristiana, llamada a ser vivida y testimoniada en la comunidad. El mal ejemplo no deriva aquí del fracaso del matrimonio pretendidamente disuelto por el divorcio, sino de la más que posible normalización de una segunda unión que la Iglesia no puede aceptar, al menos hasta que no examine la validez de la primera.

En general, los casos dudosos habrán de resolverse con sentido de la prudencia, que no significa ignorar el problema real ni tampoco dejarse llevar de un rigorismo que pudiera ser humillante para los fieles, que, después del fracaso de su matrimonio y del nuevo fracaso (objetivo) que comportó el matrimonio civil tras el divorcio permitido por la ley estatal, sienten la necesidad de una conversión, llaman a las puertas de la Iglesia y quieren participar en la vida comunitaria. Como escribe Ortiz, «la decisión de admitirlos o no a las diversas funciones se tomará en atención a las circunstancias del caso concreto, las disposiciones de los fieles, su actitud frente a los deberes familiares y el respeto del bien de la indisolubilidad, el esfuerzo por adecuarse a la normativa eclesial, el alejamiento del riesgo de escándalo para los demás fieles, etc.» ${ }^{62}$.

Además, como advierte Sánchez-Gil, la eventual decisión de no admitir a determinadas responsabilidades eclesiales a los divorciados que hayan contraído nuevo matrimonio civil, debe ir acompañada en cada caso de una adecuada explicación de las razones que justifiquen la negativa, de modo que esos fieles entiendan que no se trata de una exclusión definitiva, sino más bien de un aplazamiento, hasta que sean idóneos para asumir aquellas responsabilidades, una vez que hayan profundizado con la gracia de Dios en su conversión personal ${ }^{63}$.

${ }^{62}$ M. A. ORTiz, También llamados a la santidad..., cit., 135. También es importante lo que señala Trevisan: «Inoltre, per salvaguardare il rispetto e la dignità delle persone, tali ulteriori proibizioni devono richiedere da parte dei pastori una dovuta informazione e spiegazione come pure un'applicazione omogenea senza discriminazioni. Non si vuole infatti giudicare la persona, ma tutelare la comunità dal possibile scandalo»: G. TREVISAN, I divorziati risposati..., cit., 258 (la cursiva es mía).

${ }^{63}$ Cfr. A. S. SÁnCHEZ GIL, La pastorale dei fedeli in situazioni di manifesta indisposizione morale..., cit., 576. 


\section{APERTURA Y NO DISCRIMINACIÓN}

Algunos católicos divorciados y unidos en matrimonio civil (más bien pocos, por desgracia) se convierten con la ayuda de Dios y se proponen una vida cristiana. El magisterio de la Iglesia da algunas orientaciones, que ya hemos recordado, para que los divorciados vueltos a casar puedan ser bien recibidos en su vuelta al hogar y no sean humillados ni discriminados. Así, deben ser animados sobre todo a escuchar la Palabra de Dios y a la oración para madurar en la fe, si es posible con la ayuda de un director espiritual. También les incumbe la participación en la liturgia, especialmente la misa dominical, pero sin acercarse a recibir la santísima eucaristía ni tampoco el sacramento de la penitencia, mientras no se propongan firmemente cambiar su estilo de vida, renunciar a los actos propios de los esposos y evitar el escándalo. Especialmente importante en esa situación es el ejercicio de las obras de caridad y de misericordia, pues la caridad cubre la muchedumbre de los pecados ${ }^{64}$. La participación en asociaciones de fieles puede ayudarles a ser acogidos en un ambiente de fraternidad cristiana. Naturalmente, parte principalísima de su vida cristiana es la tarea de educar bien a los hijos.

En este escrito he incluido ya algunas apreciaciones sobre el hecho de que las llamadas de Amoris laetitia y del Sínodo de 2015 a evitar formas de exclusión de los divorciados vueltos a casar y a una mayor integración de éstos en las comunidades cristianas son pertinentes, pero podrían ser mal entendidas. Parece necesario establecer algunas distinciones, sobre todo para no confundir la discriminación con cualquier planteamiento prudente respecto de la participación de aquellos fieles en la vida pública de la Iglesia. La discriminación es una distinción injusta, es decir, que no viene justificada desde la verdadera igualdad de los fieles en la misión de la Iglesia. Sin embargo, no cualquier distinción, no cualquier límite, equivale a una discriminación. Que los divorciados vueltos a casar, porque son christifideles, sigan siendo receptores de la llamada a participar en la vida de la Iglesia no significa que puedan ser admitidos a cualquier tarea o responsabilidad, como podría serlo cualquier otro fiel que no se haya divorciado y vuelto a casar.

En este contexto la necesidad de evitar posibles discriminaciones negativas, es decir «formas de exclusión» injustificadas (por seguir la terminología del Sínodo de 2015) no debería confundirse con lo que en la filosofía política

${ }^{64}$ Cfr. 1 Pe 4,8. 
contemporánea se denominan «discriminaciones positivas»; es decir, las actividades políticas y jurídicas dirigidas a promocionar socialmente a grupos de ciudadanos que se encuentran en situación de desventaja frente a otros, como pueden ser los grupos de emigrantes, minorías raciales, discapacitados, etc. A mi juicio, estaría completamente fuera de lugar plantear un estilo de discriminación positiva a favor de los divorciados vueltos a casar que les abra las puertas de manera general a los oficios eclesiásticos. Esa política eclesial no podría ser justificada por un supuesto espíritu de desagravio frente a posibles afrentas cometidas contra esos fieles en épocas pasadas.

\section{CONCLUSIÓN GENERAL}

El repaso de la doctrina magisterial y de las normas que se han presentado en estas páginas demuestra, a mi juicio, que no resulta posible afirmar que la deseada «integración» de los divorciados y vueltos a casar en la vida de la comunidad cristiana comporte la participación en todos aquellos oficios eclesiásticos no reservados a los clérigos. Pero al mismo tiempo, es necesaria siempre una valoración del caso concreto, que tenga en cuenta, por una parte, la relevancia social y pública de la función que se ejerce y, por otra, el posible escándalo y confusión que se derivarían de mantener en esa responsabilidad a un fiel que se ha divorciado y vuelto a casar.

Como hemos visto, el magisterio de la Iglesia, subraya la realidad objeti$\mathrm{va}^{65}$ de la situación en la que se encuentran esos fieles. Es una situación que contradice el significado propio de la alianza matrimonial y una de sus propiedades características que es la indisolubilidad. Además, el magisterio eclesiástico subraya fuertemente el problema también objetivo del escándalo que produce esa situación en la comunidad eclesial; sobre todo para los fieles más débiles, que en este caso son los que no tienen una adecuada formación acerca del sacramento del matrimonio.

Se puede evocar aquí la gran enseñanza sobre la vocación universal a la santidad, expresada con claridad por el Concilio Vaticano II ${ }^{66}$. Existe el peligro de considerar de manera insuficiente esta doctrina tan evangélica y a la vez

${ }^{65}$ Cfr. aquí, C. J. Errázuriz M., Matrimonio y justicia objetiva en la comunión eclesial: un aspecto del discernimiento pastoral propiciado por «Amoris laetitia», en este número de Ius Canonicum (pp. 731-738).

${ }^{66}$ Además de otros lugares del Vaticano II, cfr. especialmente const. Lumen gentium, cap. V («vocación universal a la santidad en la Iglesia»). 
tan característica de la Iglesia contemporánea: como si se tratara solamente de un ideal saludable de la Iglesia, pero sin efectivas consecuencias en la vida de los fieles. Ahora bien, la llamada a la santidad es más que un mero ideal estimulante pero genérico, porque está llamada a inspirar toda la vida de la Iglesia. Consiste en una vocación, una llamada que el Señor hace a la Iglesia y a cada fiel en su concreta situación. Precisamente por eso se manifiesta como una invitación o sugerencia que no puede mandarse ni imponerse. Sin embargo, a la luz de esta doctrina, la Iglesia puede establecer, como de hecho hace, unos requisitos para la titularidad de los cargos públicos: más exigentes allí donde la responsabilidad asumida ante la comunidad sea mayor.

Las personas que se encuentran en situaciones matrimoniales irregulares, por recordar de nuevo la terminología de Familiaris consortio, dan un testimonio objetivo de un comportamiento que no es compatible con la vocación a la santidad, puesto que supone la aceptación de un estilo de vida directamente contrario a la indisolubilidad del matrimonio, don de Dios que comporta una exigencia moral en correspondencia a la gracia. Y esto al margen de que subjetivamente esas personas se encuentren en unas condiciones que disminuyan su responsabilidad moral, o incluso no permitan decir que se encuentran en pecado. En tales casos no es la condición subjetiva de esas personas la que es juzgada por la autoridad eclesiástica, sino su idoneidad para dar un testimonio público y social, a través del cargo o responsabilidad que asumen, de la santidad de vida que se pide a todos los fieles. 


\section{Bibliografía}

Adeva MarTín, I., Escándalo, en Gran Enciclopedia Rialp, VIII, Rialp, Madrid 1972, 741-743.

AZnar GIL, F. R., Divorciados, casados civilmente de nuevo y recepción de la comunión eucarística: Declaración del Consejo Pontificio para la Interpretación de los Textos Legislativos (24 junio 2000). Texto y comentario, Revista española de derecho canónico 58 (2001) 249-273.

—, El debate sinodal (2014) sobre la situación eclesial de los fieles divorciados y casados de nuevo civilmente, Apollinaris 87 (2014) 447-485.

—, El Sinodo de los obispos (2015): la «propositio» sobre los fieles divorciados y casados de nuevo civilmente, Revista española de derecho canónico 72 (2015) 349-366.

AZNAR GIL, F. R. - FleCHA ANDRÉs, J. R., Admisión a la comunión eucarística de los divorciados y casados civilmente de nuevo, Salmanticensis 42 (1995) 235-277.

Baura, E., Primacía de la persona. Misericordia, «oikonomia» y derecho, en N. Álvarez de las Asturias (ed.), En la salud y en la enfermedad. Pastoral y derecho al servicio del matrimonio, Cristiandad, Madrid 2014, 75-111.

Bogarín DíAz, J., Repercusiones canónicas de «Amoris laetitia», Revista general de derecho canónico y derecho eclesiástico del Estado 41 (2016) (www.iustel.com), 64 pp.

BURKe, R. L., Canonical questions regarding the proposed pastoral care of the faithful who are divorced and have attempted marriage, The Jurist 75 (2015) 273295.

CAFFARRA, C., Ontología sacramental e indisolubilidad del matrimonio, en R. Dodaro (ed.), Permanecer en la verdad de Cristo. Matrimonio y comunión en la Iglesia católica, Cristiandad, Madrid 2014, 181-194.

DAMmacco, G., I divorziati tra diritti e conversione, en O. Fumagalli CARUlli - A. Sammassimo (a cura di), Famiglia e matrimonio di fronte al Sinodo. Il punto di vista dei giuristi, Vita e pensiero, Milano 2015, 169-179.

De PaOlis, V., Los divorciados vueltos a casar y los sacramentos de la eucaristía y de la penitencia, en R. Dodaro (ed.), Permanecer en la verdad de Cristo. Matrimonio y comunión en la Iglesia católica, Cristiandad, Madrid 2014, 195-226.

—, Matrimonio y evangelización: cuestiones de teología y derecho canónico, trad. esp., BAC, Madrid 2015.

EJEH, B., The principle of suitability in the provision of ecclesiastical offices in the 1983 Code of Canon Law, Ius Ecclesiae 20 (2008) 569-592. 


\section{ANTONIO VIANA}

ERDÖ, P., Elementos de un sistema de las funciones públicas en la Iglesia según el Código de Derecho Canónico, Ius Canonicum 33 (1993) 541-552.

ERrÁZUriz M., C. J., Matrimonio e giustizia oggettiva nella comunione ecclesiale: un aspetto del discernimento pastorale auspicato da «Amoris laetitia», en Ius Canonicum 56 (2016) 731-738.

FRANCESCHI, H., Divorziati risposati e nullità matrimoniale, en H. FRANCESCHI - M. A. ORTIZ (a cura di), Ius et matrimonium. Temi di diritto matrimoniale e processuale canonico, Edusc, Roma 2015, 109-140.

GRANADOS GARCÍA, J., Eucaristía y divorcio: ¿hacia un cambio de doctrina?, BAC, Madrid 2014.

Gronchi, M., Alcune questioni disputate nella Relatio finalis del III Sinodo straordinario, en L. SABBARESE (a cura di), Sistema matrimoniale canonico in synodo, Urbaniana University Press, Roma 2015, 19-40.

Miele, M., Papa Francesco e gli sviluppi recenti del metodo sinodale, en O. Fumagalli Carulli - A. SAMmassimo (a cura di), Famiglia e matrimonio di fronte al Sinodo. Il punto di vista dei giuristi, Vita e pensiero, Milano 2015, 317-345.

Montan, A., Ministeria, munera, officia. I laici titolari di uffici e di ministeri (cann. 228, 230, 274): precisazioni terminologiche, en GRUPPO ITALIANO DOCENTI DI DIRITTO CANONICO (a cura di), I laici nella ministerialità della Chiesa: XXVI Incontro di Studio, Glossa, Milano 2000, 99-134.

Müller, G. L., Testimonio a favor de la fuerza de la gracia: sobre la indisolubilidad del matrimonio y el debate acerca de los divorciados vueltos a casar y los sacramentos, en R. Dodaro (ed.), Permanecer en la verdad de Cristo. Matrimonio y comunión en la Iglesia católica, Cristiandad, Madrid 2014, 163-194.

Navarro-Valls, R., Matrimonio y Sínodo sobre la familia: influencia de factores culturales, en O. Fumagalli CARUlli - A. SAMmassimo (a cura di), Famiglia e matrimonio di fronte al Sinodo. Il punto di vista dei giuristi, Vita e pensiero, Milano 2015, 365-383.

Ortiz, M. A., También llamados a la santidad. La pastoral de los fieles divorciados vueltos a casar civilmente, en N. ÁLVAREZ DE LAS ASTURIAS (ed.), En la salud y en la enfermedad. Pastoral y derecho al servicio del matrimonio, Cristiandad, Madrid 2014, 113-157.

OTADUY, J., Relación jurídica de los profesores de religión en España. La dimensión canónica, Ius Canonicum 46 (2006) 445-489.

—, El mandato de la autoridad eclesiástica para enseñar disciplinas teológicas, Folia theologica et canonica III, 27/17 (2014) 99-122. 
Peña García, C., Aportaciones y retos del documento final del Sínodo de la familia, Manresa 88 (2016) 143-154.

Pompedda, M. F., Problemáticas canónicas, en CONGREgación PARA LA DOCTRINA DE LA FE, Sobre la atención pastoral de los divorciados vueltos a casar. Documentos, comentarios y estudios, trad. esp., Palabra, Madrid 2000, 73-80.

PREE, H., «Unio irregularis». Der Sakramentenempfang von Geschiedenen, geschiedenen Wiederverheirateten, ehelos Zusammenlebenden und nur zivil verehelichten Katholiken nach kanonischem Recht, en K. LÜDICKE - H. PAARHAMMER - D. A. BINDer (hsg. v.), Neue Positionen des Kirchenrechts, Styria Medienservice, Graz 1994, 119-152.

RATZINGer, J., Introducción, en CONGRegación PARA La Doctrina DE LA FE, Sobre la atención pastoral de los divorciados vueltos a casar. Documentos, comentarios y estudios, trad. esp., Palabra, Madrid 2000, 9-35.

RonZANI, P., La questione dei divorziati e risposati civilmente alla luce della Relazione finale del Sinodo 2015, Stato, Chiese e pluralismo confessionale (www.statochiese.it) 6 (2016) 22 pp.

SáNCHEZ GIL, A. S., La pastorale dei fedeli in situazioni di manifesta indisposizione morale, Ius Ecclesiae 26 (2014) 555-578.

SCHOCKenHOFf, E., La Chiesa e i divorziati risposati: questioni aperte, trad. it., Queriniana, Brescia 2014.

Scola, A., La famille, sujet d'évangelisation. Note en vue de la XIVe Assemblé ordinaire du Synode des Évêques, Nouvelle revue théologique 137 (2015) 561586.

Trevisan, G., I divorziati risposati possono assumersi delle responsabilità nella vita della Chiesa?, Quaderni di Diritto Ecclesiale 6 (1993) 249-260.

VALDRINI, P., Il Sinodo dei vescovi nel pontificato di papa Francesco. Riflessioni di un canonista, en O. Fumagalli Carull - A. Sammassimo (a cura di), Famiglia e matrimonio di fronte al Sinodo. Il punto di vista dei giuristi, Vita e pensiero, Milano 2015, 477-489.

VIANA, A., La comprobación de la idoneidad para el oficio eclesiástico y el orden sagrado, Ius Ecclesiae 28 (2016) 345-366.

—, Organización del gobierno en la Iglesia, Eunsa, Pamplona ${ }^{3} 2010$. 
